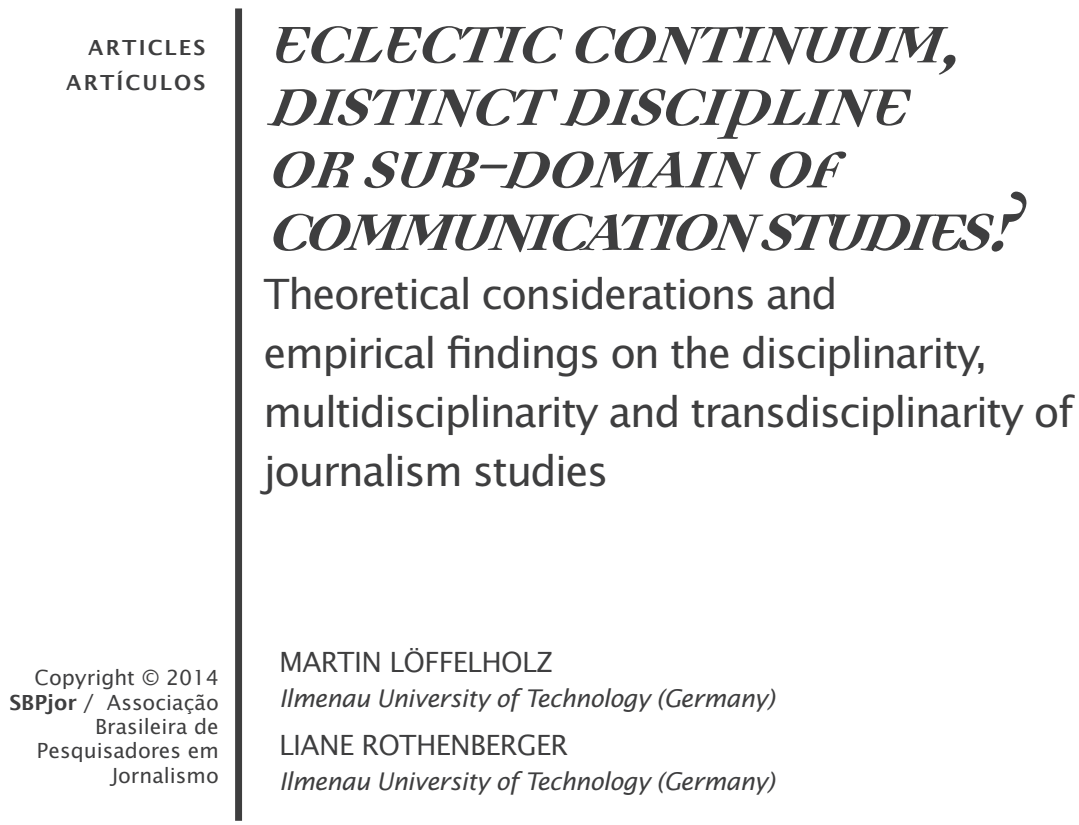

\begin{abstract}
Is journalism studies a sub-domain of communication studies, adistinct discipline, a multidisciplinary merger or a transdisciplinary endeavour? This question is discussed by analyzing the 2008 and2009 volumes of seven academic journals focusing on journalismresearch. The sample includes 349 articles published in BrazilianJournalism Research, Ecquid Novi, Journalism \& CommunicationMonographs, Journalism \& Mass Communication Quarterly, PacificJournalism Review, Journalism Studies, or Journalism: Theory,Practice and Criticism. Overall, the findings reveal that journalismresearch mainly applies theoretical approaches and empiricalmethods deriving from other disciplines, particularly sociology, psychology or cultural studies. In many countries, however, journalism studies has reached a comparatively high level of institutionalization indicated by the large number of specific schools, professorships, professional associations and respective academic journals. In conclusion, we argue that journalism studies is a sub-domain of communication studies, which integrates andtranscends various disciplines aiming to become one of the axialsubjects of the 21 st century.
\end{abstract}

Keywords: Journalism Research. Transdisciplinarity. Interdisciplinarity.

\title{
CONTINUUM ECLÉTICO, DISCIPLINA DISTINTA OU SUBDOMÍNIO DOS ESTUDOS DE COMUNICAÇÃO? Considerações teóricas e conclusões empíricas a respeito da disciplinaridade, multidisciplinaridade e transdisciplinaridade dos estudos de jornalismo
}

RESUMO - Os estudos de jornalismo são um subdomínio dos estudos decomunicação, uma disciplina distinta, uma fusão multidisciplinar ou uma tentativa transdisciplinar? Discute-se esta questão, neste artigo, através da análise dos volumes de 2008 e 2009 de sete publicações acadêmicas que focalizam a pesquisa em jornalismo. A amostra inclui 349 artigos publicados na Brazilian Journalism Research, Ecquid Novi: African Journalism Studies, Journalism \& Communication Monographs, Journalism \& Mass Communication Quarterly, Pacific Journalism Review, Journalism Studies e Journalism: 
Theory, Practice and Criticism. De modo geral, as conclusões revelam que a pesquisa em jornalismo utiliza principalmente as abordagens teóricas e os métodos empíricos derivados de outras disciplinas, especialmente da sociologia, da psicologia e dos estudos culturais. Entretanto, em muitos países os estudos de jornalismo já alcançaram um nível comparativamente alto de institucionalização, indicado pelo grande número das escolas específicas, dos cargos de professor, das associações profissionais e das respectivas publicações acadêmicas. Concluímos por defender a tese de que os estudos de jornalismo são um subdomínio dos estudos de comunicação que integra e transcende várias disciplinas visando se tornar uma das matérias mais importantes do século XXI. Palavras-chave: Pesquisa em jornalismo. Transdisciplinaridade. Interdisciplinaridade.

\section{¿CONTINUO ECLÉCTICO, DISCIPLINA DISTINTA O SUBDOMINIO DE LOS ESTUDIOS DE COMUNICACIÓN? Consideraciones teóricas y conclusiones empíricas a propósito de la disciplinariedad, multidisciplinariedad y transdisciplinariedad de los estudios de periodismo}

RESUMEN - ¿Los estudios de periodismo son un subdominio de los estudios de comunicación, una disciplina distinta, una fusión multidisciplinaria o una tentativa transdisciplinaria? Se discute esta cuestión a través del análisis de los volúmenes de 2008 y 2009 de siete publicaciones académicas que focalizan la investigación en periodismo. La muestra incluye 349 artículos publicados en Brazilian Journalism Research, Ecquid Novi: African Journalism Studies, Journalism \& Communication Monographs, Journalism \& Mass Communication Quarterly, Pacific Journalism Review, Journalism Studies, y Journalism: Theory, Practice and Criticism. De manera general, las conclusiones revelan que la investigación en periodismo utiliza principalmente enfoques teóricos y métodos empíricos derivados de otras disciplinas, en especial de la sociología, la psicología y los estudios culturales. Sin embargo, en muchos países los estudios de periodismo ya han alcanzado un nivel comparativamente alto de institucionalización, indicado por el gran número de escuelas especificas, cargos de profesor, asociaciones profesionales y publicaciones académicas. Como conclusión, defendemos la tesis de que los estudios de periodismo son un subdominio de los estudios de comunicación que integra y trasciende varias disciplinas con vistas a convertirse en una de las materias más importantes del siglo XXI. Palabras clave: Investigación en periodismo. Transdisciplinariedad. Interdisciplinariedad.

\section{INTRODUCTION}

Journalism studies is a pluralistic, differentiated and dynamic field of research and "one of the fastest growing areas within the larger discipline of communication research and media studies", as the editors of the "Handbook of Journalism Studies" recently pointed out (WAHL-JORGENSEN \& HANITZSCH, 2009, p. xi). On the other hand, it is assumed that "journalism's study emerges from and through different interpretive communities" (ZELIZER, 2004, p. 13) based on various academic disciplines, particularly sociology, history, language studies, political science, and cultural analysis, just to name the subjects explicitly discussed by Barbie Zelizer in her plea to take journalism seriously (ZELIZER, 2004, p. 45-202).

Despite its apparent multidisciplinary roots, in the $21 \mathrm{st}$ 
century journalism studies has reached a comparatively high level of disciplinary institutionalization across the globe, as evidenced by the large number of specific schools, professorships and professional associations. U.S. universities began to teach journalism in the humanities around 1900. The first American journalism schools were established by 1927; other countries followed suit decades later (ZELIZER, 2004, p. 15-21). In Germany, the scholarly interest in journalism increased at the beginning of the 20th century. However, the institutionalization of journalism schools started not before the 1970s (LÖFFELHOLZ, 1989). In Brazil, journalism as a subject of research caught the attention of scholars such as Adelmo Genro Filho at the same time. Nevertheless, many journalism schools were set up later, in the 1990s (TRAQUINA, 2005a, p. 14).

Further indicators of a disciplinary institutionalization of journalism studies are the number and focus of academic journals contributing to the scholarship on journalism. According to their titles, no less than seven English language periodicals are primarily committed to journalism research, namely (in alphabetical order) the Brazilian Journalism Research, Ecquid Novi: African Journalism Studies, Journalism \& Communication Monographs, Journalism \& Mass Communication Quarterly, Pacific Journalism Review, Journalism Studies, and Journalism: Theory, Practice and Criticism. Subsequently some authors describe journalism studies as a "fledgling discipline" aiming at the "multidisciplinary study of journalism" (FRANKLIN et al., 2005, p. XV).

Undoubtedly, the study of journalism has benefited from theoretical approaches and empirical research methods derived from diverse social sciences and humanities. However, the impact of these multidisciplinary roots on contemporary journalism research is unclear. It is questionable whether or not journalism studies simply uses the knowledge of other disciplines, thereby creating an eclectic and rather disconnected continuum of theories and methods ("multidisciplinarity"). Or does journalism studies, as its institutionalization process suggests, already achieve the status of a distinct academic discipline with its own epistemologies, assumptions, topics, and methods ("disciplinarity")? Or does journalism studies remain an area or sub-domain of another subject, namely media and communication studies, by primarily using its epistemologies and methods ("subdisciplinarity")? Last but not least, journalism studies could also be perceived as a transdisciplinary 
endeavour tying multiple subjects as well as the "space" between them enabling new perspectives "beyond" the disciplines involved ("transdisciplinarity").

Discussing its disciplinarity, subdisciplinarity, multidisciplinarity or transdisciplinarity helps to better position journalism studies within the social sciences and humanities as well as the broader scientific sphere. In this article, we aim to locate the disciplinary status of journalism studies by applying two methods: First, we elaborate the development and state of the theoretical discourse on journalism since the emergence and modification of ideas, approaches, theories, concepts, and paradigms are signs of the disciplinary autonomy of an academic subject field. Second, we describe the actual situation of journalism research by presenting major findings of a content analysis of the 2008 and 2009 volumes of the seven aforementioned academic journals. The results help detect which paradigms and theoretical approaches are taken up by researchers at present and which empirical methods dominate the field. Furthermore, the findings reveal the complex interconnectedness of journalism studies with other academic subjects.

\section{MULTIDISCIPLINARY ORIGINS: THE THEORETICAL DISCOURSE ON JOURNALISM}

The multidisciplinary origins of theoretical approaches used in journalism studies are remarkable. The theoretical perspectives range from normative approaches and psychological or sociological middle range theories, to organizational theories as well as gender and cultural studies, to name a few. The large number and heterogeneity of theoretical approaches that developed due to the growing relevance of communicator research worldwide make it difficult to give a consistent overview of the theoretical foundations of journalism studies (LÖFFELHOLZ, 2008, p. 15).

The editors of the "Handbook of Journalism Studies" distinguish four phases of journalism studies:

While the field came out of normative research by German scholars on the role of the press in society, it gained prominence with the empirical turn, particularly significant in the United States, was enriched by a subsequent sociological turn, particularly among Anglo-American scholars, and has now, with the global-comparative turn, expanded its scope to reflect the realities of a globalized world (WAHL-JORGENSEN \& HANITZSCH, 2009, p. 4). 
While the first three phases are well-documented (e.g., LÖFFELHOLZ, 2008), the global-comparative turn seems to be still at its infancy. Generally speaking, there is no consensus that the globalization of communication will be the axial principle of future journalism research, even if internationalization and globalization certainly had and will have an impact on journalism and its academic analysis (LÖFFELHOLZ \& WEAVER, 2008).

As figure 1 illustrates, the origins of journalism studies are manifold. In principal, theoretical approaches of journalism studies (depicted as circles in dark grey) emerged from a huge variety of theoretical ideas (little grey dots). The large number of approaches can be grouped and classified by identifying their commonalities in terms of origins, basic assumptions, and notions, among others.

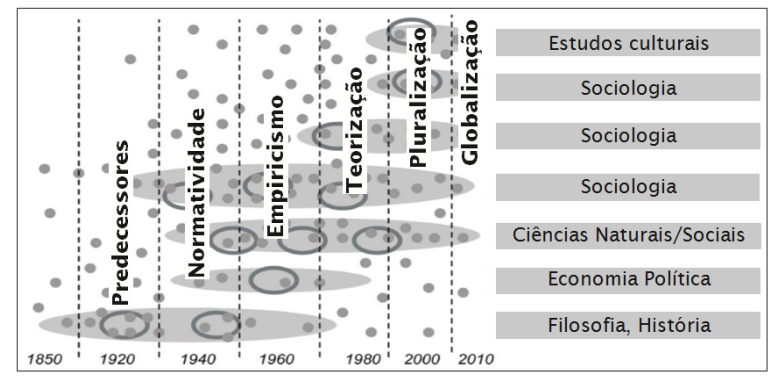

Figure 1: Disciplinary origins and phases of journalism studies (own depiction)

Seven basic theoretical concepts of journalism studies have been distinguished (here depicted as ellipses in light grey): normative individualism originating from philosophy and history, materialistic media theories derived from political economy, analytical (and legitimistic) empiricism grounded in the natural and social sciences, theories of action, systems theories, and social-integrative theories based on sociological approaches, and cultural studies (LÖFFELHOLZ, $2000,2003,2008)$. Based on these general remarks, we are now briefly describing and analyzing the emergence of the various concepts used in contemporary journalism studies.

Normative and historical-descriptive research on journalism can be already found in the middle of the 19th century. One of the early researchers in journalism, even though he did not call himself so, was Robert Eduard Prutz. In 1845, he presented a descriptive "History of German journalism" (PRUTZ, 1971 [1845]). This is significant in the 
sense that Prutz already focused not on 'media' such as newspapers and magazines but on 'journalism'. Prutz also identified journalism as being a social area that operates in relation to other social areas, and did not reduce it to the work of individual journalists. In this respect, he was ahead of his time (and ahead of many later approaches to journalism), even though his ideas did not have a significant effect on the 19th century's humanities (LÖFFELHOLZ, 2008, p. 16).

For a long time, researchers across the globe concentrated on an individualistic and normative understanding of journalism, particularly using hermeneutic and historic approaches derived from the humanities. As a result, the very first phase of journalism studies draws its epistemologies and paradigms especially from philosophy and history: "A história do jornalismo é muitas vezes escrita como a biografia dos 'grandes homens"' (TRAQUINA, 2005b, p. 60). When researchers in the U.S. began to conduct studies with special attention to journalistic production and the journalists' labour context, their work was rather sceptically received by practitioners who labeled these efforts "Mickey Mouse studies" (ZELIZER 2004, p. 20). Even though the "high noon" of normative and individualistic ideas in journalism studies is over, they still can be found in both journalistic practice and theoretical approaches to the field (e.g., DUCHKOWITSCH et al., 2009).

Individualism and normativism were rapidly losing their dominant role when researchers started to use the repertoire of empirical methods in psychology, sociology and political science. U.S. communication researcher Wilbur Schramm pioneered empiricism relying on the works of Harold Lasswell (rooted in political sciences), Paul Felix Lazarsfeld (sociology) and Carl Hovland (social psychology). The success of empiricism, first in the U.S. and then in other parts of the world, led to a reorientation of journalism studies. Journalism researchers were then focusing more on empirical research. Their fields of interest included the journalist's behaviour and decisionmaking processes - a research tradition introduced by David Manning White's gatekeeper approach in the 1950s. Early gatekeeper studies still featured methodological individualism, but soon the researchers realised that news production is a complex process, relying not only on the work of individuals. This led to an inclusion of organizational theories based on management studies and sociology (LÖFFELHOLZ, 2008 , p. 18). Other sociological theories also found their way into journalism research and communication studies (e.g., action theories 
such as the rational choice theory).

Borrowing from the social sciences helped journalism studies to better identify structural influences on journalistic work, opened access toward a multitude of theoretical ideas and approaches, and moved journalism studies closer to the empirical social sciences. This is why journalism studies as a field of research relies mostly on methods coming from psychology or sociology (e.g., in-depth interviewing, participatory observation or surveying). Cultural and language studies also contributed to the pool of research methods. Conversation analysis, for example, helped develop discourse analysis which received broad attention in Anglo-American psychology and then found its way into communication and journalism studies. The only research method primarily created in communication studies and then applied in journalism research is content analysis. In conclusion, the empirical turn in journalism studies is not the result of a distinct disciplinary endeavour but derives primarily from social sciences and cultural and language studies.

Empirical research laid also the foundation of another phase in journalism studies. The elaboration of systems' theories and social-integrative theories as a perspective for describing journalism began with an empirical study of a newspaper's editorial department as an organized social system. Based on ideas of the sociologists Talcott Parsons (1902-79) and Niklas Luhmann (192798), the German scholar Manfred Rühl conducted in the 1960s the first empirical study that focused on an organized social system instead of journalistic individuals (LÖFFELHOLZ, 2008, p. xi) One of the predecessors of Rühl's study was Warren Breed's well-received article "Social Control in the Newsroom: A Functional Analysis" (BREED, 1955).

Rühl rejected the existing normative and individualistic concepts of journalism, claiming that "the person as a paradigm is a much too complex and inelastic term to serve as a unit of analysis for journalism. In response to this, the term 'social system' is suggested, which permits differentiation between journalism and its environments" (RÜHL, 1980, p. 435-9). Rühl conducted a case study on the structures and function of the newsroom which manifested a hitherto unknown perspective: 
Editorial action, in the form of producing newspapers in a highly industrially developed society system, is not only carried out by some editors collecting messages, correcting, and writing, but is rather a fully rationalized production process in an equally rationalized and differentiated organization (RÜHL, 1969, p. 13).

In journalism research in the 1990s, not only was the systems theoretical approach refined but also the search for social 'integration' theories began. These are the theories that could overcome the dichotomy of system and subject, and of structure and action. The hierarchy-of-influences-model, for instance, developed by American scholars Pamela SHOEMAKER and Stephen D. REESE (1996), is linking individual, structural and normative factors in order to describe how media content is produced (LÖFFELHOLZ, 2008, p. 21). Thus, scholars more and more tried to link micro-, meso- and macro-levels of journalism and investigated the different interactions that lead to news production, viewing "as notícias como uma 'construção' social, o resultado de inúmeras interações entre diversos agentes sociais" (TRAQUINA, 2005a, p. 28).

Besides inputs from sociology, journalism studies are influenced by ideas and concepts coming from cultural studies (LÖFFELHOLZ, 2000; RAABE, 2005, p. 76-95). For example, British scholar John Hartley and German researcher Margreth Lünenborg urged the primarily sociology-driven community of journalism academics to overcome their narrow focus on communicator research and to stop the "exclusion of the audience" (LÜNENBORG, 2005 , p. 20). According to them, news should be regarded as a cultural product and journalism studies should not only focus on hard news but also on the coverage of fashion, travel, and human interest stories, as well as narrative forms of journalism (LÜNENBORG, 2005, p. 13-4).

Undoubtedly, it is necessary to take into account the cultural implications of journalism, particularly in comparative journalism research which is increasingly enriching our knowledge on structures, actors, and products of journalism. Trying to better understand the similarities and differences of journalism cultures across the globe "has become one of the most fascinating sub-domains in the field of journalism studies, and researchers in this area increasingly adopt a comparative perspective" (HANITZSCH, 2009,p. 413).

It is questionable, however, whether or not the apparent economic globalization leads to a "global-comparative turn" in journalism studies as, among others, Wahl-Jorgensen and Hanitzsch 
assume by pointing to the new possibilities of communication and collaboration in a globalized world:

\begin{abstract}
Journalism researchers are finding more and more opportunities to meet with colleagues from afar, made possible by the end of the cold war and increasing globalization. New communication technologies have triggered the rise of institutionalized global networks of scientists, while it has become much easier to acquire funding for international studies. As journalism itself is an increasingly global phenomenon, its study is becoming an international and collaborative endeavour (WAHL-JORGENSEN; HANITZSCH, 2009, p. 6).
\end{abstract}

Contrary to this optimistic assumption, it seems that a majority of studies on journalism still focus on news production in Western nations. Researchers from Africa, Asia and Latin America are nevertheless encouraged to make their voices heard and overcome the dominating "Westernization" or "Western bias" in journalism studies (WASSERMAN; DE BEER, 2009). It is an empirical question as to what extent journalism studies has already succeeded in globalizing its topics, research foci and theoretical approaches.

\title{
1 INTERDISCIPLINARY CONNECTEDNESS:
} THE STATE OF JOURNALISM RESEARCH

Analyzing academic articles published in journals devoted to journalism research helps us better understand the status of journalism studies within academic disciplines, sub-domains of research, and innovative transdisciplinary endeavours. While the theoretical discourse in journalism studies is mainly based on well-established other disciplines, particularly the social sciences, as explained earlier, research activities do not necessarily reflect an entire theoretical debate but may show specific paradigms, concepts, approaches, methods and topics. As a result, the findings of our content analysis of two recent volumes of academic journals indicate the actual acceptance or non-acceptance of specific research traditions and allow conclusions on the contemporary status of journalism studies.

As mentioned previously, we have included in the analysis seven academic journals which use the term "journalism" in their title. We assume that doing so reflects the journals' conceptual focal point. Since we are interested in discussing disciplinary boundaries 
- or openness - of journalism studies, we concentrated on scholarlydriven journals and excluded periodicals which turn more toward the practice of journalism or journalism education. In addition to journals with a global target group, we intentionally included three English language journals representing African, Asia-Pacific and South American scholarship on journalism which so far has been marginalized or neglected by Western academia. Every one of the seven journals adheres to a peer-review system and publishes between two to six issues yearly (cf. table 1).

Table 1: Academic journals focusing on journalism research

\begin{tabular}{|c|c|c|}
\hline Journal & Publisher & $\begin{array}{c}\text { Issues per } \\
\text { year }\end{array}$ \\
\hline $\begin{array}{c}\text { Journalism \& Mass } \\
\text { Communication } \\
\text { Quarterly }\end{array}$ & $\begin{array}{l}\text { Association for Education } \\
\text { in Journalism \& Mass } \\
\text { Communication }\end{array}$ & 4 \\
\hline Journalism Studies & Routledge & 6 \\
\hline $\begin{array}{l}\text { Journalism - Theory, } \\
\text { Practice and Criticism }\end{array}$ & Sage & 6 \\
\hline $\begin{array}{l}\text { Journalism \& } \\
\text { Communication } \\
\text { Monographs }\end{array}$ & $\begin{array}{l}\text { Association for Education } \\
\text { in Journalism \& Mass } \\
\text { Communication }\end{array}$ & 4 \\
\hline Ecquid Novi & $\begin{array}{l}\text { University of Wisconsin } \\
\text { Press et al. (since 2008) }\end{array}$ & 2 \\
\hline $\begin{array}{c}\text { Brazilian Journalism } \\
\text { Research }\end{array}$ & $\begin{array}{c}\text { Brazilian Journalism } \\
\text { Researchers Association }\end{array}$ & 2 \\
\hline $\begin{array}{l}\text { Pacific Journalism } \\
\text { Review }\end{array}$ & $\begin{array}{c}\text { Auckland University of } \\
\text { Technology }\end{array}$ & 2 \\
\hline
\end{tabular}

The sample includes 349 articles published in the 2008 and 2009 volumes of the said journals. We did not encode editorials, obituaries, and book reviews as we studied only the refereed articles. In total we coded 182 articles printed in 2008 and 167 in 2009.1 The slightly smaller number in 2009 is due to the fact that Journalism: Theory, Practice and Criticism published a special 10th anniversary issue in June 2009 which did not contain standard, refereed articles but 38 short essays and editorial and book reviews which could not be used for the purpose of this study. 
Table 2: The sample of the study (number and proportion of articles)

\begin{tabular}{|c|c|c|c|c|}
\hline Journal & Frequency & Percentage & $\begin{array}{c}\text { Valid } \\
\text { percentage }\end{array}$ & $\begin{array}{c}\text { Accumulated } \\
\text { percentage }\end{array}$ \\
\hline $\begin{array}{c}\text { Journalism } \\
\text { \& Mass } \\
\begin{array}{c}\text { Communication } \\
\text { Quarterly }\end{array}\end{array}$ & 68 & 19.5 & 19.5 & 19.5 \\
\hline $\begin{array}{c}\text { Journalism } \\
\text { Studies }\end{array}$ & 99 & 28.4 & 28.4 & 47.9 \\
\hline $\begin{array}{c}\text { Journalism - } \\
\text { Theory, Practice } \\
\text { and Criticism }\end{array}$ & 66 & 18.9 & 18.9 & 66.8 \\
\hline $\begin{array}{c}\text { Journalism \& } \\
\text { Communication } \\
\text { Monographs }\end{array}$ & 13 & 3.7 & 3.7 & 70.5 \\
\hline $\begin{array}{c}\text { Ecquid Novi } \\
\text { Brazilian } \\
\text { Journalism } \\
\text { Research }\end{array}$ & 21 & 6.0 & 6.0 & 76.5 \\
\hline $\begin{array}{c}\text { Pacific } \\
\text { Journalism } \\
\text { Review }\end{array}$ & 43 & 11.2 & 11.2 & 87.7 \\
\hline \multicolumn{1}{|c|}{ Total } & 349 & 100.0 & 100.0 & -- \\
\hline
\end{tabular}

To ensure the reliability of encoding, 12 out of 349 articles (3.4\%) were encoded by two encoders. Out of 588 possible coding decisions the encoders differed in only 46 single cases, 542 times they decided on the same value of a variable. Thus, the inter-coder reliability coefficient measured $r=.92$. Mostly, it was the category "theoretical focus" that led sometimes to different coding decisions. The main reason for those differences is that in many contributions the authors did not state clearly and explicitly their theoretical background.

The field of journalism research that the authors studied in their articles was encoded according to the classical heuristic framework of Harold D. Lasswell (1948) in his well-known formula: "Who says what in which channel to whom with what effect?" If the respective studies focused on the "Who" we coded "communicator research", if they focused on "What" we coded "media content research", and so forth. Multiple were possible. Communicator research ranks in first place. Almost two-thirds of all articles dealt 
with this field of journalism studies, followed by media content research (49.6\%). Then a big gap occurs: Just about $15 \%$ of studies focused on audience research in journalism while less than $10 \%$ of all articles presented data or observations relating to the channel or medium. Table 3 shows how the research fields are represented in the seven journals. In almost all journals communicator research and research on media content are the most important research fields.

Table 3: Campos Research fields in journalism studies (in percent)

\begin{tabular}{|c|c|c|c|c|}
\hline Journal & $\begin{array}{c}\text { Communicator } \\
\text { Research }\end{array}$ & $\begin{array}{c}\text { Research on } \\
\text { media content }\end{array}$ & $\begin{array}{c}\text { Reserach } \\
\text { on médium/ } \\
\text { channel }\end{array}$ & $\begin{array}{c}\text { Audience } \\
\text { research }\end{array}$ \\
\hline Global & 64.5 & 49.6 & 9.2 & 14.6 \\
\hline $\begin{array}{c}\text { Journalism } \\
\text { \& Mass } \\
\text { Communication } \\
\text { Quarterly }\end{array}$ & 35.3 & 58.8 & 4.4 & 44.1 \\
\hline $\begin{array}{c}\text { Journalism } \\
\text { Studies }\end{array}$ & 68.7 & 47.5 & 16.2 & 5.1 \\
\hline $\begin{array}{c}\text { Journalism - } \\
\text { Theory, Practice } \\
\text { and } \\
\text { Criticism }\end{array}$ & 78.8 & 39.4 & 1.5 & 10.6 \\
\hline $\begin{array}{c}\text { Journalism \& } \\
\text { Communication } \\
\text { Monographs }\end{array}$ & 84.6 & 53.8 & 7.7 & 15.4 \\
\hline $\begin{array}{c}\text { Ecquid Novi } \\
\text { Bcazilian }\end{array}$ & 71.4 & 28.6 & 28.6 & 14.3 \\
\hline $\begin{array}{c}\text { Bournalism } \\
\text { Research }\end{array}$ & 61.5 & 61.5 & 10.3 & 10.3 \\
\hline $\begin{array}{c}\text { Pacific } \\
\text { Journalism } \\
\text { Review }\end{array}$ & 72.1 & 53,5 & 2.3 & 0.0 \\
\hline
\end{tabular}

One of the most important questions to be answered by our empirical study is linked to the theoretical foci of journalism research. To have a solid instrument for grouping the large number of distinct theoretical approaches into sections, we applied a taxonomy developed by one of the authors of this article about a decade ago. As mentioned earlier, Martin Löffelholz has distinguished a number of basic theoretical concepts of journalism research, namely normative 
individualism, materialist media theories, analytical and legitimistic empiricism, (critical) theories of action, systems theories, integrative social theories, and cultural studies. Each concept sums up a number of specific theoretical approaches which are similar in terms of their origins, notions, and basic assumptions, among others. For an indepth elaboration of this meta-theoretical classification, please refer to previously published contributions (LÖFFELHOLZ, 2000, 2003, 2008). If the coder was not able to relate the applied theory to one of the abovementioned concepts, the coder used a separate string variable taking note of the respective approach. It was also possible to tag that there was no theory applied at all.

Table 4: Theoretical foci of journalism studies

\begin{tabular}{|c|c|c|c|c|}
\hline $\begin{array}{c}\text { Main theoretical } \\
\text { focus }\end{array}$ & Frequency & Percentage & $\begin{array}{c}\text { Valid } \\
\text { percentage }\end{array}$ & $\begin{array}{c}\text { Accumulated } \\
\text { percentage }\end{array}$ \\
\hline $\begin{array}{c}\text { Normative } \\
\text { individualism }\end{array}$ & 24 & 6.9 & 8.3 & 8.3 \\
\hline $\begin{array}{c}\text { Materialist } \\
\text { theories of media }\end{array}$ & 3 & 0.9 & 1.0 & 9.3 \\
\hline $\begin{array}{c}\text { Analytical } \\
\text { empiricism }\end{array}$ & 110 & 31.5 & 37.9 & 47.2 \\
\hline $\begin{array}{c}\text { Legitimistic } \\
\text { empiricism }\end{array}$ & 21 & 6.0 & 7.2 & 54.5 \\
\hline $\begin{array}{c}\text { Theories of } \\
\text { action }\end{array}$ & 23 & 6.6 & 7.9 & 62.4 \\
\hline $\begin{array}{c}\text { Systems theories } \\
\text { Integrative social } \\
\text { theories }\end{array}$ & 11 & 3.2 & 3.8 & 66.2 \\
\hline $\begin{array}{c}\text { Cultural studies } \\
\text { Total }\end{array}$ & 290 & 83.1 & 100.0 & 67.6 \\
\hline
\end{tabular}

If we leave articles apart that either did not mention a specific theoretical focus or relate to an approach which does not fall under the described taxonomy (16.9\%) and let the remaining 290 articles equal $100 \%$, almost two-fifths of these contributions (37.9\%) use theories 
related to paradigm of analytical empiricism. One-third applies conceptual assumptions in cultural studies. The other categories, namely normative individualism, critical theories of action, and legitimistic empiricism, are apparently not as relevant. The remaining three theoretical concepts are even more unused in international journalism studies. The materialist media theories are considered irrelevant since the Iron Curtain came down and most socialist regimes were forced to give up. Sociological systems theories as well as integrative social theories, even though much appreciated in Germanspeaking countries, do not reach out to other parts of the world yet.

When looking at the relevance of analytical empiricism in detail, a remarkably high percentage of studies is related to middlerange theories, specifically agenda-setting (about $10 \%$ of all 349 articles) and theories of news selection such as gatekeeping, news bias, or the news values theory (8\%). These theories can easily be combined with empirical research and have a solid standing in the theoretical portfolio of journalism studies.

Table 5: Theoretical or empirical foci of journalism studies

\begin{tabular}{|c|c|c|}
\hline Theoretical / empirical focus & Frequency & Percentage \\
\hline Mainly theory & 109 & 31.2 \\
\hline $\begin{array}{c}\text { Mainly empirical findings: single } \\
\text { study }\end{array}$ & 200 & 57.3 \\
\hline $\begin{array}{c}\text { Mainly empirical findings: } \\
\text { comparative study }\end{array}$ & 40 & 11.5 \\
\hline Total & 349 & 100.0 \\
\hline
\end{tabular}

As shown in table 5 , it is not surprising that more than two-thirds of all articles (68.8\%) present empirical research, mostly concentrating on single case studies. Only slightly more than $10 \%$ offered results of comparative studies on countries, journalistic cultures, or the like. This single figure allows neither identifying a global-comparative turn in journalism studies nor neglecting a possible paradigmatic change. Future research would show whether or not comparative studies are increasing.

Studies merely relying on theoretical considerations account for almost one-third of all analyzed articles. These studies do not 
use an empirical approach, yet sometimes present empirical data not necessarily gathered by the authors. Studies concentrating on empirical research use various methods, many of them developed in early German or U.S. sociology or social psychology. Particularly in the 1940s, Jewish emigrants from Nazi-Germany improved their methodological ideas in the U.S. and thereby contributed to establishing a diverse canon of meanwhile classical research methods.

According to our findings, the quantitatively most relevant empirical research method of journalism studies is content analysis (43.4\%). In-depth or guided interviews rank second and are used in about one-fifth of the analyzed studies. Paper-based surveys as well as observations are applied in less than 10\% of the analyzed articles, whereas oral and online polls as well as experiments do not belong (at least not yet) to the standard repertoire of journalism research. Multiple coding was allowed.

Table 6: Dominant research methods in journalism studies

\begin{tabular}{|c|c|c|}
\hline Empirical research method & Frequency & Percentage \\
\hline content analysis & 151 & 43.3 \\
\hline in-depth / guided interviews & 70 & 20.1 \\
\hline (paper) based survey & 29 & 8.3 \\
\hline observation & 27 & 7.7 \\
\hline standardized oral survey & 13 & 3.7 \\
\hline online survey & 13 & 3.7 \\
\hline (laboratory) experiment & 11 & 3.2 \\
\hline
\end{tabular}

By excluding approximately one-quarter of articles (24.4\%) which do not use any empirical research method, we constructed a "method-sample" of $n=264$ articles. Out of these 264 articles, 210 follow a single-method-design. The remaining 54 articles have multi-methodological approaches. The majority combine two different methods, but in six cases even three different methods are used. Out of the six special studies, three combine content analysis, in-depth interviews, and observation. Looking at the multi-methodological studies in general, $37 \%$ use content analysis 
along with in-depth interviews, $24 \%$ combine in-depth interviews and observation, and $13 \%$ have content analysis and paper-based surveys.

Correlating the usage of research methods and theoretical approaches identifies a strong relationship of content analysis and the concept of analytical empiricism. Seventy percent of all 110 articles referring to analytical empiricism present results of a content analysis. For example, many "classical" studies on news value theory use content analyses to detect certain news factors. We discovered also a significant correlation between content analysis and cultural studies. In more than two-fifths of all cultural studies-based articles (43.6\%) the researchers conducted a content analysis. Moreover, cultural studies are also closely linked to indepth interviews (23.4\%). Studies based on the theoretical concept of legitimist empiricism are strongly related to in-depth interviews (42.9\%) as well as to paper-based surveys (23.8\%). This could be explained by the fact that legitimist empiricism is primarily interested in the motivation, self-concept, and political affiliation of journalists, as well as their images of colleagues and audience (LÖFFELHOLZ, 2003, p. 35).

Table 7: Share of studies using content analysis or in-depth interviews (in percent)

\begin{tabular}{|c|c|c|}
\hline Journal & $\begin{array}{c}\text { Content } \\
\text { analysis }\end{array}$ & $\begin{array}{c}\text { In-depth } \\
\text { interviews }\end{array}$ \\
\hline $\begin{array}{c}\text { Journalism \& Mass } \\
\text { Communication Quarterly }\end{array}$ & 45.6 & 5.9 \\
\hline Journalism Studies & 51.5 & 23.2 \\
\hline $\begin{array}{c}\text { Journalism - Theory, Practice and } \\
\text { Criticism }\end{array}$ & 37.9 & 34.8 \\
\hline $\begin{array}{c}\text { Journalism \& Communication } \\
\text { Monographs }\end{array}$ & 53.8 & 30.8 \\
\hline Ecquid Novi & 38.1 & 42.9 \\
\hline Brazilian Journalism Research & 43.6 & 10.3 \\
\hline Pacific Journalism Review & 27.9 & 7.0 \\
\hline
\end{tabular}


By correlating the application of research methods with the respective journals, we detected that except for Pacific Journalism Review all journals have most of their studies showing results from content analyses or in-depth interviews. Confirming the findings of the correlation of theoretical foci and the usage of research methods, all journals present a majority of articles based on content analysis and centre analytical empiricism. For example, of all articles published in Journalism and Mass Communication Quarterly which elaborated a theoretical focus, more than twothirds could be categorized as belonging to analytical empiricism (68.9\%). Similar results are found in Journalism and Communication Monographs (41.7\%), Brazilian Journalism Research (40.6\%) and Journalism: Theory, Practice and Criticism (40\%). In comparison, Ecquid Novi focus more on cultural studies (65\%), and the same is true for Journalism Studies (47.7\%) and Pacific Journalism Review (42.9\%). Thus, two groups of academic journals could be distinguished - i.e., those devoted more to cultural studies and those focused more on the empirical-analytical paradigm.

More than one-fourth of all articles published by the journals (27.8\%) do not focus on a specific medium but discuss general aspects such as theories, conditions for the professionalization of journalists, general cognitive effects, and other topics. As regards the type of media that journalism researchers are most interested in, newspaper still dominates journalism research as object of study: It ranks first in every journal. Somehow, this is surprising, considering the much longer time audiences watch television rather than reading newspapers and, even more obvious, the increasing relevance of online media. A possible explanation is that content analyses of print media are easier to handle than the analysis of audio, video or online materials. However, online media and television are also important in journalism research (17.5\% and $15.8 \%$, respectively). As the Internet gets more and more relevant even in rural areas of the world, it is advisable to analyse this development in the future. On the other hand, it would be also interesting to look at past volumes of journalism studies periodicals and, for instance, trace back at which point in time the Internet "overtook" television. 
Table 8: Media-type orientation in journalism studies (in percent; multiple choices possible)

\begin{tabular}{|c|c|c|c|c|c|}
\hline Journal & Newspaper & Magazine & Radio & Television & Online \\
\hline Global & 38.7 & 7.7 & 8.0 & 15.8 & 17.5 \\
\hline $\begin{array}{c}\text { Journalism \& Mass } \\
\text { Communication } \\
\text { Quarterly }\end{array}$ & 33.8 & 11.8 & 4.4 & 17.6 & 23.5 \\
\hline $\begin{array}{c}\text { Journalism Studies } \\
\text { Journalism- Theory, }\end{array}$ & 46.5 & 4.0 & 8.1 & 12.1 & 18.2 \\
\hline $\begin{array}{c}\text { Practice and Criticism } \\
\text { Journalism \& } \\
\text { Monmugraphs }\end{array}$ & 31.8 & 4.5 & 6.1 & 16.7 & 12.1 \\
\hline $\begin{array}{c}\text { Ecquid Novi } \\
\text { Monazilian Journalism } \\
\text { Research }\end{array}$ & 38.1 & 0.0 & 33.3 & 9.5 & 0.0 \\
\hline $\begin{array}{c}\text { Pacific Journalism } \\
\text { Review }\end{array}$ & 32.6 & 11.6 & 11.6 & 18.6 & 9.3 \\
\hline
\end{tabular}

Due to its growing relevance, media as an object of journalism research were examined in greater detail. We found several possibilities to highlight the role of the Internet in research: For example, there are studies covering governments' websites, content management systems, websites, and news content of social movements as well as topics related to search engines or wikis. However, the largest portion of studies focus on social media, such as blogs, e-communities (e.g., facebook, xing), multimedia platforms like the photo-sharing platform flickr or the video-sharing platform YouTube. In almost two-fifths of studies dealing with Internet-related issues (39.3\%) the authors wrote about blogs or bloggers, in $8.2 \%$ about multimedia platforms, in $4.9 \%$ about e-communities, and $3.3 \%$ dealt with micro-blogging services like twitter. Furthermore, we asked whether or not the studies focus on content provided by professional journalists (journalistic websites) or on user-generated content, e.g., online newsgroups or bulletin boards. The results show that the analysis of professionally produced news 
content so far outnumber the investigation of user-generated content ( $72.1 \%$ and $27.9 \%$, respectively). Hence, journalism research still sticks to analyzing content of professional journalists which shows that the traditional understanding of journalism as a professional practice still prevails.

In comparison, studies on magazines and radio are not as popular in journalism research. Less than $10 \%$ of articles of all analyzed journals choose these types of media as research objects. The high percentage of analyses of magazine journalism in Journalism \& Communication Monographs should be seen in relation to the small number of articles in the said journal - there are only 13 articles (cf. table 2). A reason for the unusually high percentage of articles in Ecquid Novi dealing with radio journalism is most likely related to the importance of radio in rural African areas as well as in countries that tried or still try to change the people's democratic rights with the help of the media. Some articles published in Ecquid Novi cover for example the community radio in Nigeria. Wire services are also included in our study but they are not more than $2.6 \%$ of all articles.

Regarding the territorial or regional focus of journalism studies, it is not surprising that the three journals with a regional focus in their titles, namely Ecquid Novi: African Journalism Studies, Brazilian Journalism Research and Pacific Journalism Review, mainly highlight issues connected with African, Latin American, Australian, and Pacific journalism. Among others, topics include post-apartheid journalism, Australian Federal Press Gallery, or the coverage of the Maori party's election campaign.

Table 9: Regional foci of journalism research (multiple answers possible)

\begin{tabular}{|c|c|}
\hline Regional focus & Percentage \\
\hline North America & 36.9 \\
\hline Europe & 25.5 \\
\hline Australia / New Zealand / Oceania & 14.8 \\
\hline Latin America & 11.7 \\
\hline Asia & 10.1 \\
\hline Africa & 8.7 \\
\hline
\end{tabular}


Fifty-one articles do not focus on a specific country. If we exclude these articles from the total sample $(n=349)$, there are 298 articles left applying a specific country focus. Using this sample as a base $(298=100 \%)$, we identified a strong share of $36.9 \%$ of articles dealing with North America, particularly the U.S., while about one-fourth deals with aspects of journalism in European countries (on the assumption that we counted Turkey as an Asian country). Australia, New Zealand and Oceania are represented by $14.8 \%$ of the articles, Latin America by $11.7 \%$, Asia by $10.1 \%$, and Africa by $8.7 \%$. These disproportional regional foci of journalism research reflect an important aspect of journalism studies' reality: Despite the optimistic idea of a global-comparative turn, journalism research today is still enormously dominated by Western research endeavours. This general finding is, on the one hand, underlined by the disproportional distribution of specific countries. On the other hand, our study shows that besides traditional boundaries between the industrialized and the developing worlds, there are also language barriers hindering a specific national journalism research to raise international or even global attention. While 108 articles are dealing with the U.S., 31 with the United Kingdom and 29 with Brazil, Germany which has a strong journalism research tradition is mentioned in only six articles. Another interesting result related to the assumption of a global turn in journalism studies is that less than $10 \%$ of all articles explicitly came up with intercultural or international aspects (9.2\%).

The interdisciplinary connectedness of journalism studies is known to all researchers staying temporarily in the field. Our findings show the disciplinary links deemed more important than others (cf. table 10). While the variety of disciplinary links is impressive, the strongest relationship is with politics and political science. Technology, history and advertising follow, whereas links to public relations, entertainment and economy are less relevant. 
Table 10: Disciplinary links of journalism research

\begin{tabular}{|c|c|c|}
\hline Disciplinary link & Frequency & Percentage \\
\hline Politics & 141 & 40.4 \\
\hline Technology & 52 & 14.9 \\
\hline History & 35 & 10.0 \\
\hline Advertising & 30 & 8.6 \\
\hline Public relations & 16 & 4.6 \\
\hline Entertainment & 13 & 3.7 \\
\hline Economy & 9 & 2.6 \\
\hline $\begin{array}{c}\text { Other (culture, law, military, } \\
\text { religion, science, sports etc.) }\end{array}$ & 8 & 2.3 \\
\hline No specific disciplinary link & 45 & 12.9 \\
\hline Total & 349 & 100.0 \\
\hline
\end{tabular}

Interestingly, some of the most important links of journalism research, namely advertising, public relations, and entertainment, point at topics analyzed under communication studies. This shows the special connectivity of subject areas belonging to the analysis of specific forms of communication and the public sphere which are fields of research claimed to be main objects of communication studies.

The great variety of topics linked to different disciplinary fields underlines the liveliness and openness of journalism studies. Journalism researchers are interested in a variety of topics like agricultural journalism, photojournalism, language of journalistic products, investigative journalism, caricatures as journalistic formats, campus journalism, coverage of war, music journalism, censorship, freedom of the press, media monitoring, personalities in journalism, missionary journalism, video journalism, job situation in journalism, news browsing, plagiarism, copyright laws, press access to government records, the use of new technologies for journalistic investigation, gratuitous magazines, coverage of female suicide attackers, rebranding, bilingual journalism, the relevance of Foucault's theories for journalism studies, target groups of newspapers, obituary notices, 
citizen journalism, photos of female politicians, watchdog journalism, leaks, data mining, and grassroots journalism.

According to our findings some research themes and their disciplinary links are more important than others, at least if we take into account how often topics are handled in the analyzed articles. More than one-fifth of the studies (20.6\%) deal with aspects regarding the structure and organization of journalism, for example in editorial offices or news rooms, or structures resulting from regulatory bodies (with disciplinary links to management studies and sociology). Articles dealing with topics such as ethics, values or normative demands in journalism accounted for $16 \%$ of the total sample (with disciplinary links to philosophy, political science, and sociology). On the other hand, less than five percent of the articles focused on globalization or Europeanization (4.6\%), reflecting the still low relevance of the paradigm of globalization in journalism research. However, eight percent of articles explicitly concentrated on gender or race aspects, indicating that the discourse on cultural hybridization has already reached journalism research.

\section{CONCLUSION AND OUTLOOK}

At the beginning of the 21 st century, journalism studies has reached a certain level of institutionalization. The number of journalism schools and professorships specializing in research and training may be described as satisfactory, although the institutionalization process differs from country to country. Across the globe journalism is not only taught by specialized departments and faculty members but also through various disciplines, mainly under communication and media studies and sometimes also under language studies and other humanities. The institutionalization of journalism research has also progressed. Many academic journals have devoted much of their content to the production of news and most scholarly associations in the area of communication have established specific divisions aimed at bringing together researchers interested in the study of journalism. As a result journalism studies shows signs of disciplinarity (especially in terms of the institutionalization of journalism education) and at the same time benefits from its status as a research sub-domain of communication studies.

Our analysis of the theoretical discourse on journalism has proven that the origins and developments of journalism studies are 
based on multidisciplinary roots primarily from the social sciences and humanities. Sociology and cultural studies mainly contributed to the contemporary state of journalism theory. In sum, the actual theoretical discourse is rich, heterogeneous, and full of competing ideas. A number of middle-range theories may be perceived as specific outcomes of journalism studies. However, most, if not all, may also be connected with communication studies in general. Similarly, it is almost impossible to identify distinct epistemologies of journalism studies. The methodologies and research methods used in journalism studies have been developed by disciplines such as sociology or social psychology and are applied in all social sciences, including communication and media studies. Stimuli for innovations in journalism theory are often based on debates which started outside journalism studies, e.g., Pierre Bourdieu's field theory or Anthony Gidden's assumptions on the duality of structures and their transfer into journalism studies (LÖFFELHOLZ, 2008). As regards the origin and state of epistemologies and theories journalism studies subsequently do not fulfil the provisions of identifying it as a distinct discipline.

On the contrary, it appears that journalism studies loosely combines manifold approaches created by various disciplines without discussing in detail their interconnections or integration potentials. Communication scholar Barbie Zelizer noted some years ago:

\footnotetext{
The contemporary study of journalism has divided journalism scholars not only from each other but also from other parts of the academy. Within it are deep pockets separating groups of people who share concerns for the past, present, and future of journalism but lack a shared conversational platform for their concerns. They include journalism educators, journalism scholars in communication and media studies departments, writing teachers interested in the texts of journalism, technology scholars involved in information transfer (ZELIZER, 2004, p. 3).
}

It remains to be seen as to which direction journalism studies should move to overcome its division into separate interpretative communities. Is it advisable to work on attaining the status of a distinct discipline? Is this goal achievable given the lack of specific epistemologies and its eclectic multidisciplinarity? Or should journalism studies rather accept or advance its status as a subdomain of communication studies?

From our point of view, journalism studies would benefit from its role as a sub-domain since communication studies unites all areas of research related to media and communication, including journal- 
ism. Both journalism studies and communication studies are closely linked to sociology, psychology, information technology, linguistics, literature, political science, and history, among others. This gives journalism studies the chance to make use of its interdisciplinary approaches and experiences despite its subdisciplinary status. Moreover, the broader perspective of communication studies makes it easier to surmount cultural, national, and disciplinary boundaries enabling a truly global research on journalism (WEAVER;LÖFFELHOLZ, 2008, p. 8 ). Finally, communication studies transcends various disciplines and aims to become one of the axial academic subjects of the 21 st century. This is not an obstacle but an opportunity to journalism studies.

\section{NOTE}

1 We are grateful to undergraduate student Matthias Jahn (Ilmenau University of Technology, Germany) who encoded all 349 articles and filled 17.101 SPSS table fields. We also thank Professor Danilo A. Arao from the Department of Journalism at the University of the Philippines, Diliman, who helped editing the manuscript and gave useful hints to improve grammar and style.

\section{REFERENCES}

BREED, Warren. Social Control in the Newsroom: A Functional Analysis. In: Social Forces, 33, 326-335, 1955.

DUCHKOWITSCH, Wolfgang et al. Journalistische Persönlichkeit. Fall und Aufstieg eines Phänomens [Journalist Personalities. Decline and rise of a phenomenon]. Köln: Herbert von Halem, 2009.

FRANKLIN, Bob et al. Key Concepts in Journalism Studies. London, u.a.: Sage, 2005.

HANITZSCH, Thomas: Comparative Journalism Studies. In: WAHLJORGENSEN, Karin Wahl-Jorgensen; HANITZSCH, Thomas (Eds.). Handbook of Journalism Studies. New York: Routledge, 2009. p. 413427.

LASSWELL, Harold D. The Structure and Function of Communication in Society. In: BRYSON, L. (Ed.). The Communication of Ideas: A series of Addresses. New York: Harper and Brothers, 1948. 
LÖFFELHOLZ, Martin: Politik im Wissenschaftssystem. Planung und Implementation der hochschulgebundenen Journalistenausbildung [Politics in the system of science. Planning and implementation of academic journalism education]. Münster: Lit, 1989.

Theorien des Journalismus. Ein diskursives Handbuch [Journalism theories. A discursive handbook]. Wiesbaden: Westdeutscher Verlag, 2000.

. Kommunikatorforschung: Journalistik [Communicator Research: Journalism]. In: BENTELE, Günter; BROSIUS, Hans-Bernd; JARREN, Otfried. Öffentliche Kommunikation [Public Communication]. Wiesbaden: Westdeutscher Verlag, 2003. p. 28-53.

- Heterogeneous - Multidimensional - Competing: Theoretical Approaches to Journalism - an Overview. In: LÖFFELHOLZ, Martin; WEAVER, David (Eds.). Global Journalism Research. Theories, Methods, Findings, Future. Malden, Oxford: Carlton: Blackwell, 2008. p. 15-27.

LÖFFELHOLZ, Martin; WEAVER, David. (Eds.). Global Journalism Research. Theories, Methods, Findings, Future. Malden, Oxford, Carlton: Blackwell, 2008.

LÜNENBURG, Margreth: Journalismus als kultureller Prozess. Zur Bedeutung von Journalismus in der Gesellschaft. Ein Entwurf [Journalism as cultural process. Meaning of journalism in society. An outline]. Wiesbaden: VS, 2005.

MEYEN, Michael; LÖBLICH, Maria. Klassiker der Kommunikationswissenschaft. Fach - und Theoriegeschichte in Deutschland [Classics of Communication Science. History of the subject and its theories in Germany]. Konstanz: UVK, 2006.

PRUTZ, Robert E. Geschichte des deutschen Journalismus [History of German journalism]. Göttingen: Vandenhoeck und Ruprecht, 1971 [1845].

RAABE, Johannes. Die Beobachtung journalistischer Akteure. Optionen einer empirisch-kritischen Journalismusforschung [Observation of journalist actors. Options of empirical-critical journalism studies]. Wiesbaden: VS, 2005.

RÜHL, Manfred. Journalismus und Gesellschaft. Bestandsaufnahme und Theorieentwurf [Journalism and society. Status quo and theory design]. Mainz: Hase und Koehler, 1980.

Die Zeitungsredaktion als organisiertes soziales System [The newspaper's editorial department as an organized social system]. Bielefeld: Bertelsmann Universitätsverlag, 1969.

SHOEMAKER, Pamela J.; REESE, Stephen D. Mediating the Message. Theories of Influences on Mass Media Content. 2. ed. New York: Longman, 1996. 
TRAQUINA, Nelson. Teorias do Jornalismo. Volume I: Porque as notícias são como são. Second edition. Florianópolis: Insular, 2005a.

Teorias do Jornalismo. Volume II: A tribo jornalística - uma comunidade interpretativa transnacional. Second edition. Florianópolis: Insular, 2005b.

WAHL-JORGENSEN, Karin; HANITZSCH, Thomas (Eds.). Handbook of Journalism Studies. New York: Routledge, 2009.

WASSERMANN, Herman; DE BEER, Arnold S. Towards De-Westernizing Journalism Studies.

WEAVER, David (Ed.). The Global Journalist: News people around the world. Cresskill: NJ. Hampton Press, 1998.

WEAVER, David; LÖFFELHOLZ, Martin. Questioning National, Cultural, and Disciplinary Boundaries. A Call for Global Journalism Research. In: LÖFFELHOLZ, Martin; WEAVER, David (Eds.). Global Journalism Research. Theories, Methods, Findings, Future. Malden, u.a.: Blackwell, 2008. p. 3-12.

ZELIZER, Barbie: Taking Journalism Seriously. News and the Academy. Thousand Oaks, London, New Delhi: Sage, 2004.

Martin Löffelholz is professor at IImenau University of Tecnology, Germany, and received his PhD in Communication by Münster University. Is the author of more than 10 books on Journalism.

Liane Rothenberger is journalist and Senior Researcher at Ilmenau University of Tecnology, Germany. 